\title{
Impact of Built Environment Dispersion on Urban Mobility
}

\author{
Umberto Petruccelli \\ University of Basilicata-Potenza, Italy \\ E-mail: umberto.petruccelli@unibas.it
}

Received: May 4, 2016 Accepted: May 17, 2016

doi:10.5296/emsd.v5i1.9413～URL: http://dx.doi.org/10.5296/emsd.v5i1.9413

\begin{abstract}
The scattered growth of the city is a common phenomenon occurred with a certain intensity in Europe since the early 80 s of last century, due to various causes and producing consequences in different sectors.

In this study we examined the effects of urban sprawl, on commuting mobility within the municipalities, in terms of change in modal split from which, as is known, externalities from the transport system largely depend.

To this end, with reference to a large sample of capital cities, we studied statistical relationships between specially built indicators of urban sprawl and characteristic parameters of mobility, including the modal split.

The results allowed us to consider the existence of possible cause - effect relationships between the variables examined as well as to verify the representativeness of settlement selected variables and to build some statistical models able to reproduce the interactions between urban sprawl and modal split. By these models we estimated the likely lower use of private transport resulting from a less urban sprawl and the consequences on $\mathrm{CO}_{2}$ emissions and on revenues for public transport.
\end{abstract}

Keywords: Urban sprawl, Commuting mobility, Transport modal split, Territorial indexes, Mobility indexes

\section{Introduction}

The world is experiencing from several decades a gigantic urbanization that has expanded the centre of large cities but has widened so much faster and more extensive suburbs. The tendency to a rapid and disordered expansion of the suburbs seems to connote in the future growth of the city. The characteristic sign of urban sprawl is the low settlement density which 
has negative consequences on the reduction of green areas, the land consumption and the dependence on cars because of the greater distances involved and the difficulty of public transport to serve the widespread demand that follows.

The effects of the built environment on mobility choices involved scholars mostly from the 90s. The influence, on the transport mode choice, of the travelled distances, the settlement density, the land use mingling, the network connectivity and the district attractiveness was under analysis. Many studies have shown that the inhabitants of the areas with higher density and with more various land use tend to move more walking and to use less their cars (see, for example, Duncan et al., 2010; Frank et al ., 2006). Other ones have shown that better connectivity of the road network corresponds to a greater walkability (Cervero et al., 2009) and to a lesser use of individual transport means even if the relationship in this case was less clear (Leck, 2006).

The relationships between the built environment and transport choices in the trips for reasons other than work in Japan were investigated by Parady et al., (2015), noting that a higher density settlements are greater preference for public transport at the expense of car. Olaru and Curtis (2015) found that improving the quality of transport infrastructure and the strengthening of accessibility for non-residential activities achieves a reduction in car trips.

Not many studies have investigated the specific topic of this article, namely the relationship between urban sprawl and commuting to work, especially with regard to medium and small cities.

The problem is generally quite complex because the modal choice is a consequence of the distances involved and the provision of infrastructure and transport services. The travel distance is the result of the location of the residences and working places. Therefore a decentralization of residences and at the same time of jobs, not involving more spacing of ones from the others, does not generate, in principle, the increase of home - work paths, but these latter can be of shorter time because they run through faster roads external to the city centre. Of course the dispersion of residents and workers makes it more difficult to provide an offer of effective public transit and thus it presumably directs the mobility demand toward private transport. Unlike the decentralization and dispersal toward the suburbs restricted to residences or just employees presumably increases the distance of travel for work. In any case it is certain that the phenomenon presents in time a certain tendency to rebalancing, since it drives at least part of the workers to bring their residence near to the work place.

On the specific topic, Gordon et al. (1991), by a comparison of the auto commuting trip durations from the 1985 American Housing Survey to data from 1980 census, for the twenty largest metropolitan areas, observed a paradox consisting in the decrease or invariance of the commuting average trip time against a traffic congestion that has generally been getting worse. Moreover, these trip times tended to be lower in the cities experiencing rapid growth and/or with low-density structures. The authors advanced some hypotheses to explain the observed paradox. Among these, the suburban location adjustment made by households and businesses aimed to reduce the times in commuting to work trips also using faster and less congested infrastructures. 
The effects of the decentralization of employment on the commuting to work were studied by Cervero et al. (1991) trying to establish whether ad to what a degree the relocation of office workers from a downtown to a suburban location affect commuting behaviour. From a survey of 320 former downtown San Francisco workers who now work in the suburbs, they found that the average distance travelled remains essentially unchanged and that the average commuting speed declines. The most dramatic change was the switch from public transit to private auto commuting. Furthermore, those workers who remained in San Francisco becoming inverse commuters are worst off whereas those who moved their residences out of the city are much better off in terms of transportation access.

Crane and Chatman (2002), on the basis of data detected by the American Housing Survey for several years between 1985 and 1997 about U.S. metropolitan areas, found that more suburbanized is employment, that is the more sprawl, the shorter the average commute because the shorter distance between workers and workplaces (most of the formers evidently living in suburban areas). However, the authors warn of the possibility to generalize the results, highlighting that this reduction regards the travel time (probably because decentralization allows using faster infrastructure and because residencies in US cities are widespread) and does not affect the travel length and however, non-work trips increase in number and length. Anyway the authors underline the complexity of the phenomenon that, among other things, is influenced by the progressive adaptation of residences by many workers who tend to get closer to their work place.

Vandersmissen et al. (2003) tried to identify spatial and social factors responsible for the changes in work trips, between 1977 and 1996, in Quebec City, a medium-sized Canadian metropolitan area. On the basis of a survey to a large sample, they developed a disaggregate model of trip duration and verified that the shift from a monocentric to a dispersed form is responsible, in the examined area, for increasing commuting time.

The analysis on how well the commuting patterns reflect the corresponding urban spatial structure has been developed by Sohn (2005), with reference to the Seul Metropolitan Region in 1987, 1990 and 1995. For this purpose, he derived and combined, in an adjusted gravity model, locational variables for commuting trip origin and destination. The results revealed a trend of dispersion for both employment and employed residents and also that the distribution of employment was consistent between the two distribution patterns while the distribution of employed resident was not. Furthermore the results seems to show that commuters may not always consider trip distance minimization as the primary factor in deciding their residential location, workplaces or even commuting routes, and that however employers tend to spatially gravitate towards local labour markets.

Zolnik (2011) using micro-data from the 2001 National Household Transportation Survey for individuals and micro-data on various measure on sprawl for metropolitan areas, estimated, by multilevel models, time and distance for a sample of private-vehicle commuting. He found that employment decentralization is associated with shorter commuting time. However the amount of variation in commuting times associated with employment sprawl is tiny and therefore the benefit is negligible. The results also suggest that individuals adjust their 
location within metropolitan areas so as to maintain reasonable private-vehicle commuting time.

Axisa et al. (2012) studied the influence of some population features on the commute distance within the commuter shed of Toronto in Canada. Using the data from the 2006 Census of Canada Master File, they found, among other results, that the growth in the periphery, that is urban sprawl, lead to longer commute distances.

There are fewer studies on the European cities having a quite large urban core and only from the ' 80 years have experienced relevant decentralization processes. For instance, Travisi et al. (2010), using a mobility impact index, empirically analysed the dynamics of the urban sprawl and the characteristics of the trips. They showed that, during the decade $1981-1991$ in which the sprawl has sensibly raised in Italy, the impact of commuting in the examined Italian cities has increased by up to $37 \%$ and this increment has matched a marked shift towards private motorized travel modes and a reduction of the use of public transit.

Alpkokin et al. (2008), using the available data of the Istanbul city for 1985 and 1997, built a practical utility, likely suitable for many large cities of the developed world, to identify employment clusters and their dynamics and assess impacts on commuting patterns (trip length, employment destination zonal, preference function and mode share) for each type of sub-centre identified. The authors also compare the changes in Istanbul to those found in San Francisco, Los Angeles and Chicago taken from other research works. Inter alia they have occurred that more a multi-centric structure becomes dominant, longer and more trips are likely to occur.

In this research work, referring to many cities with the same territorial role within Italy, we analysed possible relationships between some descriptive variables of the urban sprawl and some features of commuting to work mobility. The results are discussed and interpreted in the light of current knowledge, to help understand the analysed phenomena. Finally, using some of the relationships identified, we assessed the reduction in use of private cars, and thus in $\mathrm{CO}_{2}$ emissions, as well as the increase in demand and return of public transport produced by an higher concentration of the urban areas in each city.

After the definition of the subject and the reference of the main research works on it (in the present section 1), we deal with variables representing the two correlated phenomena, i.e. the urban sprawl and commuting, in section 2. The relationships derived from regressions between variables representing the two phenomena as well as their interpretation are given in Section 3, together with a possible modelling of the most significant relationships. Using some of the models, we assess, in section 4, the effects, on mobility, of an urban sprawl reduction and some consequences of these effects. Section 5 presents some brief remarks about the impact of the subject on research and policy.

\section{Methods}

As a first step we have identified the variables representative of the phenomena to be related, choosing them according to their representativeness and the availability of data at the disaggregation level of the study. 
Mobility has been described through the variables measuring the modal choice between available transport supply chances (i.e. the number of trips by public transport, by private vehicles and by non-motorized means, each related to the total commuting trips) and through the mobility index of the considered journeys (i.e. commuting to work within each capital, related to the number of inhabitants). The length of the trips was not considered because they are not systematically detected in Italy. These variables are able to measure the size of commuting purified by settlement size of the city. However, it is to be considered that, as drawn from the literature, phenomena of urban dispersion and decentralization not always and not in the same way affect the length and the time of the trips but nearly always affect the modal choice increasing the use of private vehicles. Therefore the change in modal split is the mostly relevant result of the urban sprawl on mobility.

Moreover, the modal split affects the polluting emissions and in turn it is influenced by the index of motorization and the public transit supply as well as the size of the city and the differences in height to overcome. The motorization rate (car in / 1,000 inhabitants) is a direct consequence of the income and these parameters are, respectively, an indirect measure of the availability of private vehicles and the willingness to use it, since this transport is generally more expensive. However, the motorization rate can produce different and conflicting effects on modal split. On the one hand indeed, greater availability of cars can grow their use. On the other hand, a greater number of available own cars and consequent their increased use raises congestion on the urban road network with negative effects on travel times that can play in favour of the public transport choice, especially if this transport is effective. The public transport supply per capita provides a measure of how the alternative to private vehicle is present and therefore effective in meeting the mobility needs in terms of time.

Among the variables of the territory settlement we included, in addition to the resident population in the municipality, the surface and the altitude of the main centre being understood that an higher value of this parameter indicates an higher altitude corresponding to major differences in height of the cities (both within the core, both between the different conurbations) that will certainly make movements with non-motorized transport more strenuous. Unfortunately the maximum disaggregation of the available data, which is the municipal level, did not allow to take into account the actual variability of the height within the territory of each municipality. To assume implicitly this variability to be proportional to the altitude of the main centre will not result, in most cases, a big mistake, also because the municipal area generally is rather narrow. The average age factor has been overlooked as not much different between urban centres that cover similar territorial roles (all provincial capitals). The dispersion of the settlements within the municipal (urban sprawl) is measured by several indicators described below. This is because there is no variable capable to represent alone this phenomenon characterized by multiple aspects.

The values of the modal split indicators were obtained processing the ISTAT files of commuting to work and school surveyed in the 15 th Census ${ }^{1}$ (ISTAT 2011) which, as is known, are the only data available on the mobility, detected in a uniform manner for the

\footnotetext{
${ }^{1}$ Systematic origin-destination trips for work and study were detected by ISTAT (Italian National Institute of Statistics) during the 15th Census of Population (October 9, 2011) and used by ISTAT for the definition of work local systems.
} 
entire national territory. Not having been able to take into account the non-systematic mobility and that for reasons other than work and school certainly limits the possibilities for generalization of the results found. In fact, this type of mobility, since less rigid, is certainly more sensitive to the characteristics of territory and the transport system.

Data on supply of urban public transit in the provincial capitals are drawn from the Study of the Fondazione Filippo Caracciolo (2013).

The Italian provincial capital cities considered (69 on a total of 110) are: Alessandria, Ancona, Aosta, Arezzo, Asti, Bari, Benevento, Bergamo, Bologna, Bolzano, Brescia, Brindisi, Cagliari, Campobasso, Caserta, Catania, Catanzaro, Como, Cosenza, Ferrara, Florence, Foggia, Forlì, Genoa, L'Aquila, La Spezia, Latina, Lecce, Livorno, Lucca, Matera, Messina, Milan, Modena, Monza, Naples, Novara, Olbia, Padova, Palermo, Parma, Perugia, Pesaro, Pescara, Piacenza, Pistoia, Pordenone, Potenza, Prato, Ragusa, Ravenna, Reggio Calabria, Reggio Emilia, Rimini, Rome, Salerno, Sassari, Savona, Siracusa, Taranto, Terni, Turin, Trento, Treviso, Trieste, Udine, Venice, Verona, Vicenza.

In the first instance we have tried all the possible correlations between pairs of variables to test the existence of possible statistical and collinearity ties. Subsequently, we have neglected those variable found less representative of the analysed phenomena, as described in chapter 3.

Table 1. Municipal inhabitants, surface, altitude, income, modal split and mobility rate of the internal trips for the sample of Italian provincial capitals (processing from Istat - Italian Institute of Statistics) data of 2011 population Census)

\begin{tabular}{|c|c|c|c|c|c|c|c|c|}
\hline & \multirow[b]{2}{*}{ Inhabitants } & \multirow{2}{*}{$\begin{array}{c}\text { Surface } \\
\left(\mathrm{km}^{2}\right)\end{array}$} & \multirow{2}{*}{$\begin{array}{c}\text { Capital } \\
\text { altitude } \\
(\mathrm{m})\end{array}$} & \multirow{2}{*}{$\begin{array}{c}\text { Income } \\
\text { p.c. } \\
\text { (Euro) }\end{array}$} & \multirow{2}{*}{$\begin{array}{c}\text { Mobility rate } \\
\text { (trips/inhab/day) }\end{array}$} & \multicolumn{3}{|c|}{ Modal split } \\
\hline & & & & & & Public/total & Private/total & $\begin{array}{c}\text { Non } \\
\text { motor/tot }\end{array}$ \\
\hline Average & 231.687 & 204 & 127 & 25.723 & 0,15 & 0,19 & 0,48 & 0,33 \\
\hline $\begin{array}{l}\text { Standard } \\
\text { deviation }\end{array}$ & 391.180 & 194 & 185 & 2.616 & 0,03 & 0,07 & 0,13 & 0,11 \\
\hline
\end{tabular}

Table 2. Motorization rate, supply and demand of public transport in the most of Italian provincial capitals (source: Fondazione Filippo Caracciolo, 2013)

\begin{tabular}{|l|l|l|l|l|l|l|}
\hline $\begin{array}{l}\text { Motoriz. rate } \\
\text { (cars/1000.inhab) }\end{array}$ & $\begin{array}{l}\text { PT supply } \\
\text { (ML.seats.km) }\end{array}$ & $\begin{array}{l}\text { PT demand } \\
\text { absolute values } \\
\text { (ML.pass/year) }\end{array}$ & $\begin{array}{l}\text { demand } \\
\text { relative values } \\
\text { (pass.veic/inhab) }\end{array}$ & $\begin{array}{l}\text { PT } \\
\text { demand/supply } \\
\text { absolute value } \\
\text { (pass/seats.km) }\end{array}$ & $\begin{array}{l}\text { PT } \\
\text { demand/supply } \\
\text { (pass/inhab./seats.km) }\end{array}$ \\
\hline $\begin{array}{l}\text { Average } \\
\text { Standard } \\
\text { deviation }\end{array}$ & 112 & 1,170 & 56.6 & 112 & 32,098 & 0.24 \\
\hline
\end{tabular}

The urban diffusion is evaluated, through the distribution and shape of the built areas, by the two indexes below. 


\section{Macrothink}

- Class Largest Patch Index (LPCI) expresses, in percentage, the relationship between the surface of the largest polygon among those drawn from built-up areas and the overall built-up area. It is an index of compactness, varying for the considered cities between $20 \%$ and $98 \%$ and reaches the higher values where there is a greater concentration of the built environment within the city limits and subsequently where there is a more intensive use of the soil.

- Residual Mean Patch Size (RMPS) provides, in hectares, the average size of the polygons of the built-up areas, with the exception of higher polygon, and allows to evaluate the average size of the built-up areas outside the main urban centre providing a measure of the level of spread of the urban fabric.

The measure of urban dispersion is based on the built density, the whose detected values were divided to identify three classes of density (high, medium and low). Based on this classification of areas we have built three indexes:

- Edge Density (ED), ratio, in meters / hectares, among the total perimeter of low density areas and the surface of all the built-up areas, low-medium and high density, internal to the municipal boundaries; the highest values are reached usually in discontinuous cities with urban dispersion.

- Low Density Areas ( $L D A)$, the relationship between the surface of the low-density areas, and the municipal area; It provides a measure of the incidence of the area affected by phenomena of dispersion; the calculated values are between 0.09 (Savona) and 0.71 (Latin).

- Urban Sprawl (US), the ratio between the whole surface of low density areas and the surface of all the built-up areas (low and high density) falling in the municipality; it is a measure of the incidence of areas scattered on all the built-up areas.

Furthermore, an assessment of the built environment fragmentation, taking into account the population dynamics, is expressed by Dynamic sprawl index (DSI), which measures the change over time of the built related to population. In a span of time, in the presence of a stable population, there should be no increase in the occupation of soil; if it happens, would indicate the presence of dispersion phenomena. In general the increase of occupied soil should be proportional to the increase of the population in order not to detect leakage phenomenon. The period considered for the calculation of this index is from 2000 to 2012 . The above described indexes are summarized in Table 3.

The calculated values for the set provincial capitals are taken from Bonomo et al. (2014) and are collected, as aggregate values, in table 4. 
Table 3. Indexes of urban diffusion, fragmentation and dispersion

\begin{tabular}{|c|c|c|c|c|}
\hline Scope & INDEX & Formula & Meaning & Function \\
\hline \multirow{2}{*}{$\begin{array}{l}\text { Analysis } \\
\text { of built area } \\
\text { distribution and } \\
\text { shape }\end{array}$} & $\begin{array}{l}\text { Largest } \\
\text { class Patch } \\
\text { Index } \\
\text { (LCPI) }\end{array}$ & $\begin{array}{l}L C P I=A_{p . \max } / A_{\text {build-up }} \\
\text { Rate between the area of the largest built } \\
\text { polygon and the whole built area }(\%)\end{array}$ & $\begin{array}{l}\text { It measures the city } \\
\text { consistency, by the } \\
\text { surface of the central } \\
\text { core compared with the } \\
\text { all built surface }\end{array}$ & $\begin{array}{l}\text { Decreasing with } \\
\text { the diffusion } \\
\text { (therefore } \\
\text { increasing with } \\
\text { consistency) of } \\
\text { the urban fabric }\end{array}$ \\
\hline & $\begin{array}{l}\text { Residual } \\
\text { Mean } \\
\text { Patch Size } \\
\text { (RMPS) }\end{array}$ & $\begin{array}{l}R M P S=\sum A_{\text {res.po. }} / N_{\text {res.pol. }} \\
\text { Average wideness of the built areas } \\
\text { polygons with the exclusion of the largest } \\
\text { polygon (ha) }\end{array}$ & $\begin{array}{l}\text { It measures the diffusion } \\
\text { of built areas outside the } \\
\text { central core, by the } \\
\text { average wideness; it is } \\
\text { the level of diffusion of } \\
\text { the urban fabric }\end{array}$ & $\begin{array}{l}\text { Increasing with } \\
\text { the diffusion of } \\
\text { the urban fabric }\end{array}$ \\
\hline \multirow{3}{*}{$\begin{array}{l}\text { Assessment of } \\
\text { built density }\end{array}$} & $\begin{array}{l}\text { Edge } \\
\text { Density } \\
\text { (ED) }\end{array}$ & $\begin{array}{l}E D=\sum P_{\text {edge.pol }} / N_{\text {Total.edge }} \\
\text { Rate between the perimeter of the built area } \\
\text { (or sum of the perimeters of the built areas } \\
\text { polygons) and the surface of the whole built } \\
\text { area. (m/ha) }\end{array}$ & $\begin{array}{l}\text { It measures the built } \\
\text { density; } \\
\text { it indicates the } \\
\text { fragmentation of urban } \\
\text { edges (interface between } \\
\text { built and not-built areas); } \\
\text { it analyses the border of } \\
\text { city transformation }\end{array}$ & $\begin{array}{l}\text { Increasing with } \\
\text { the lack of } \\
\text { uniformity in the } \\
\text { urban borders } \\
\text { (low values of ED } \\
=\text { compact city or } \\
\text { well-defined } \\
\text { urban center) }\end{array}$ \\
\hline & $\begin{array}{l}\text { Low } \\
\text { density } \\
\text { areas } \\
\text { (LDA) }\end{array}$ & $\begin{array}{l}L D A=A_{\text {low.dens }} / A_{\text {mun }} \\
\text { Rate between low density areas and the } \\
\text { whole municipal area }\end{array}$ & $\begin{array}{l}\text { It indicates the surface } \\
\text { concerned by dispersion } \\
\text { inside the municipal } \\
\text { territory }\end{array}$ & $\begin{array}{l}\text { Increasing with } \\
\text { the raise of the } \\
\text { municipal area } \\
\text { concerned by } \\
\text { dispersion } \\
\text { phenomenon }\end{array}$ \\
\hline & $\begin{array}{l}\text { Urban } \\
\text { sprawl } \\
\text { (US) }\end{array}$ & $\begin{array}{l}U S=A_{\text {low.dens }} / A_{\text {buildup }} \\
\text { Rate between the whole surface of low } \\
\text { density areas and the whole surface of all } \\
\text { built areas (low and high density areas) } \\
\text { inside the municipal territory }\end{array}$ & $\begin{array}{l}\text { It measures the density of } \\
\text { the discontinuous areas } \\
\text { related to the municipal } \\
\text { area; it quantifies the rate } \\
\text { of built area concerned } \\
\text { by the dispersion } \\
\text { phenomenon }\end{array}$ & $\begin{array}{l}\text { Increasing with } \\
\text { the raise of the } \\
\text { built area } \\
\text { concerned by } \\
\text { dispersion } \\
\text { phenomenon }\end{array}$ \\
\hline $\begin{array}{l}\text { Estimate of the } \\
\text { built areas } \\
\text { fragmentation } \\
\text { related to } \\
\text { population } \\
\text { dynamics }\end{array}$ & $\begin{array}{l}\text { Dynamic } \\
\text { sprawl } \\
\text { index (DSI) }\end{array}$ &  & $\begin{array}{l}\text { It measures the increase } \\
\text { of built area related to } \\
\text { the population variation } \\
\text { or else how much a built } \\
\text { area change is consistent } \\
\text { with the population } \\
\text { change. }\end{array}$ & $\begin{array}{l}\text { At existing } \\
\text { population, the } \\
\text { index increases } \\
\text { with the raise of } \\
\text { the soil } \\
\text { occupation }\end{array}$ \\
\hline
\end{tabular}


Table 4. Values of the indexes of urban diffusion, fragmentation and dispersion (source: Bonomo et al., 2014)

\begin{tabular}{|l|c|c|c|c|c|c|}
\hline & \multicolumn{4}{|c|}{ Built distribution and shape } & \multicolumn{2}{c|}{ Built area } \\
& \multicolumn{2}{|c|}{} & \multicolumn{2}{c|}{$\begin{array}{c}\text { Built density } \\
\text { fragmentation } \\
\text { related to pop. } \\
\text { dynamics }\end{array}$} \\
\cline { 2 - 7 } & LCPI (\%) & RMPS (ha) & ED (m/ha) & LDA (ratio) & US (ratio) & DSI (2000-12) \\
\hline Average & 74.5 & 7.6 & 332.5 & 0.3 & 0.6 & 10.6 \\
\hline $\begin{array}{l}\text { Standard } \\
\text { deviation }\end{array}$ & 20.4 & 4.7 & 106.4 & 0.1 & 0.2 & 7.1 \\
\hline
\end{tabular}

\section{Results}

\subsection{Some Remarks on Correlations}

Table 5 shows the determination coefficients of all the correlations between pairs of variables. It's to be noted that the statistical relationships emerging from a correlation analysis between a territory variable and a sociological or mobility one, are always weak, given that social phenomena and mobility are complex and linked to many variables that may have an even greater influence over the settlement characteristics of the territory. Therefore, values of the determination coefficient $\left(\mathrm{R}^{2}\right)$ greater than or equal to 0.1 (highlighted in yellow) indicate the presence of a presumable statistical relationship that it becomes more likely to values above 0.3 (in green) to become then, in principle, not significant for values greater than 0.5 . In fact, a very high $\mathrm{R}^{2}$ indicates a poor sensitivity of the phenomenon to variables other than that one which has been placed in relationship and that, as said before, it is very difficult to find in reality. Therefore this situation makes it likely the presence of phenomena of multi-collinearity between the variables made in connection, which means that these variables measure not dissimilar aspects of the phenomenon. Situations of this type are found between some of the indicators of dispersion used (for example, ED and US, LCPI and US) which clearly describe the same phenomenon. In other cases, a relatively high $\mathrm{R}^{2}$ confirms the existence of an intuitive relationship as it is between the population and the municipal area or between the income and the rate of motorization. Other high values of $R^{2}$ testify the existence of predictable relationships but reveal a trend very different from what we would expect. It is the case of the incidence of the motorization rate on modal choice: as discussed below, the increased availability of the individual vehicle pushes towards the choice of public transport rather than to use the same means, as we might imagine. The relationships between the population and the amount of public transport supplied per inhabitant, and between the population and the motorization rate are more expected although not obvious. Both are probably explained by the income that is higher in the most populous cities and makes it possible both to purchase a greater number of vehicles by citizens, and to supply a more massive public transport by the municipality whose financial resources grow up with those of the inhabitants.

The analysis of the emerged relations is developed in the following paragraphs. 


\section{MInstitute ${ }_{\text {Mnk }}^{\text {Macrothink }}$}

Table 5. Determination coefficients $\left(\mathrm{R}^{2}\right)$ of the simple regressions

\begin{tabular}{|c|c|c|c|c|c|c|c|c|c|c|c|c|c|c|c|}
\hline & 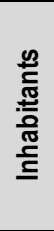 & 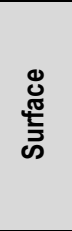 & $\begin{array}{l}\frac{0}{\frac{0}{2}} \\
\frac{\overrightarrow{3}}{\frac{1}{4}}\end{array}$ & $\begin{array}{l}\stackrel{\Xi}{\Xi} \\
\stackrel{\Xi}{\subseteq}\end{array}$ & 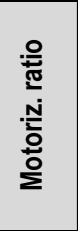 & 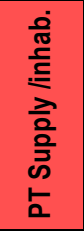 & $\overline{\mathrm{D}}$ & $\sum_{\text {\& }}^{\infty}$ & 우 & $\stackrel{\infty}{3}$ & 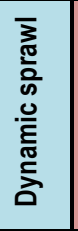 & 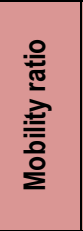 & 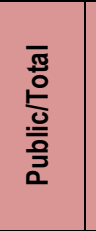 & 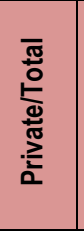 & 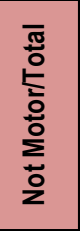 \\
\hline Inhabitants & - & 0,452 & 0,127 & 0,192 & 0,466 & 0,758 & 0,128 & 0,128 & 0,300 & 0,290 & 0,014 & 0,045 & 0,321 & 0,182 & 0,039 \\
\hline Surface & & - & 0,012 & 0,271 & 0,125 & 0,208 & 0,369 & 0,139 & 0,175 & 0,338 & 0,035 & 0,005 & 0,054 & 0,100 & 0,186 \\
\hline Altitude & & & - & 0,036 & 0,019 & 0,040 & 0,065 & 0,011 & 0,099 & 0,065 & 0,045 & 0,050 & 0,007 & 0,105 & 0,183 \\
\hline Income & & & & - & 0,373 & 0,476 & 0,228 & 0,048 & 0,236 & 0,236 & 0,018 & 0,025 & 0,025 & 0,334 & 0,223 \\
\hline Motoriz. ratio & & & & & - & 0,575 & 0,213 & 0,059 & 0,317 & 0,261 & 0,058 & 0,008 & 0,518 & 0,482 & 0,155 \\
\hline PT Supply /inhab. & & & & & & - & 0,458 & 0,204 & 0,424 & 0,421 & 0,021 & 0,026 & 0,011 & 0,393 & 0,110 \\
\hline LCPI & & & & & & & - & 0,453 & 0,482 & 0,640 & 0,012 & 0,030 & 0,026 & 0,213 & 0,213 \\
\hline RMPS & & & & & & & & - & 0,051 & 0,100 & 0,002 & 0,008 & 0,007 & 0,033 & 0,026 \\
\hline ED & & & & & & & & & - & 0,737 & 0,014 & 0,023 & 0,110 & 0,361 & 0,289 \\
\hline US & & & & & & & & & & - & 0,053 & 0,019 & 0,051 & 0,275 & 0,289 \\
\hline Dynamic Sprawl & & & & & & & & & & & - & 0,007 & 0,087 & 0,073 & 0,086 \\
\hline Mobility ratio & & & & & & & & & & & & - & 0,063 & 0,055 & 0,061 \\
\hline Public / Total & & & & & & & & & & & & & - & 0,285 & 0,001 \\
\hline Private / Total & & & & & & & & & & & & & & - & 0,73 \\
\hline Not Motor./ Total & & & & & & & & & & & & & & & - \\
\hline
\end{tabular}

\subsection{Features of Territory and Mobility}

The first result is the lack of correlation of the systematic mobility for work and study index (travel / inhab. / day) with any settlement characteristic of the whole town, such as the inhabitants, the surface or the income pro- capita. What emerged confirms that this type of mobility, probably unlike the non-systematic and for reasons other than work and study ones, essentially derives from the need, resulting in life styles which are not affected by either the size of the municipality, either in the disposable income of individuals.

Similarly we detected that the number of inhabitants in the municipality does not affect the choice of non-motorized means to carry out systematic trips for work inside the city, while favours the choice of public transport (Figure 1) and then at the expense of private transport. The found logarithmic relationship is easily explained by the sensitive difference of cost between private and public transport characterizing the longer trips, typical of major cities, as well as by the meaningful presence in the latter of transport systems on its own runway that can compete with the car for attractiveness.

The choice of pedestrian or bike transport has a nuanced relationship with the municipal surface $\left(\mathrm{R}^{2}=0.186\right.$ - Figure 2$)$, with a trend before descending quickly and then more slowly, to confirm the limits of this mode, generally accepted only for short distances. 

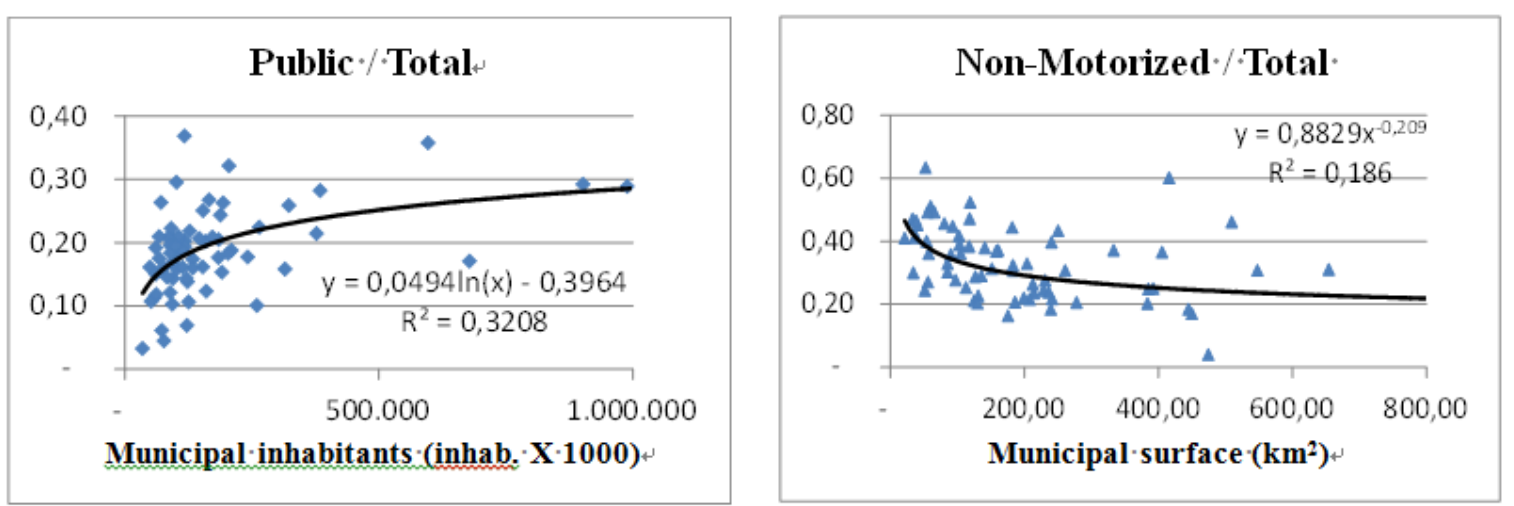

Figure 1. Number of city inhabitants and use of public transport

Figure 2. Municipal surface and non-motorized mobility

The inversely proportional correlation found between altitude of provincial capital and choice of non-motorized transport (Figure 3) that is more expected, although low, proves the sensitivity of this transport mode to the difference of height. The strong enough relationship emerged between average income and motorization index $\left(\mathrm{R}^{2}=0.46\right.$ - Figure 4) is predictable and confirms that the car is seen mainly as a consumer object rather than as a means of transport and thus it is owned a greater extent by people with higher income.
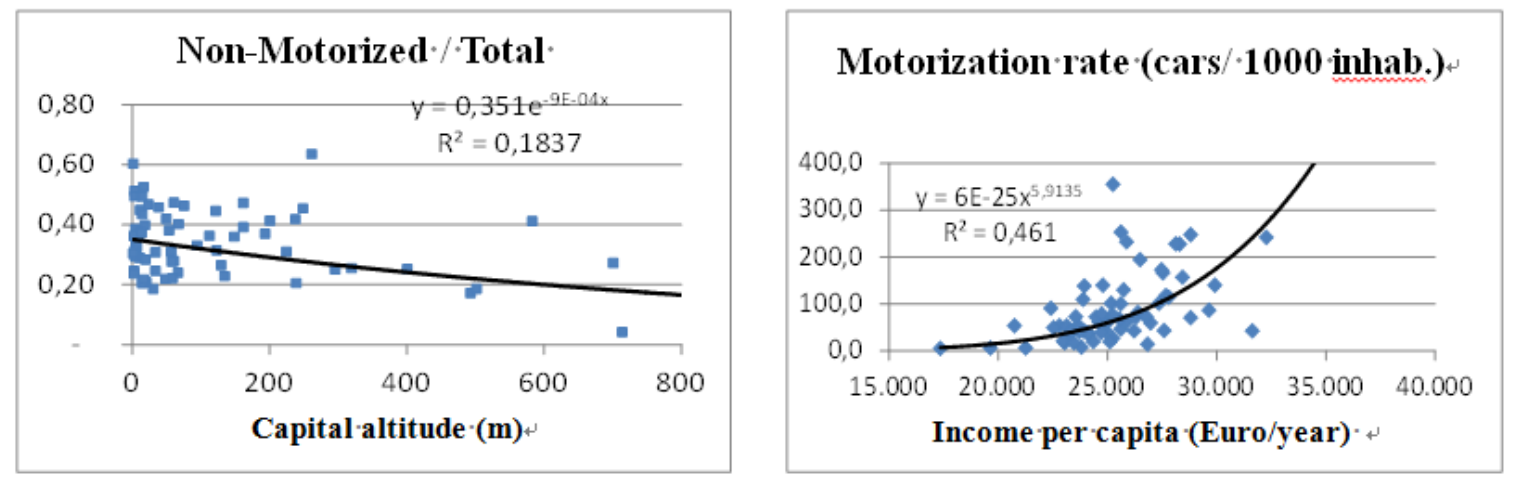

Figure 3. Capital altitude and non-motorized mobility

Figure 4. Per capita income and motorization rate

The availability of the vehicle significantly affect the modal split although so different from what you might expect. In fact, with the growth of the motorization rate and namely the availability of private vehicles, its use for urban trips, rather than increase, decreases in favour mainly of walkability and bicycle and to a lesser extent in favour of public transport (Figure 5). This has a likely motivation in obvious congestion problems that the presence of the car (more sensitive in the larger cities) causes but we must not underestimate the influence of an indirect factor to be found in the size of the city (in proportion of which the income and the motorization rate grow) and consequently the greater length of trips that makes "heavier" the cost of travel by car.

Relationships (Figure 6) between income per capita and modal split are more nuanced (thus 
with lower $\mathrm{R}^{2}$ ). Even in these ones, detected trends are unexpected: the increase in income leads to choose non-motorized and public transport instead of the car, more expensive, while the motorization rate growing with the same income. The motivation is to be found, as well as in environmental awareness "more mature" presumably attributable to the user with the highest income (assuming that the highest income is the consequence of a higher cultural level), mostly in an indirect effect of congestion and in a better public transport supply usually found in larger cities where there are higher incomes.
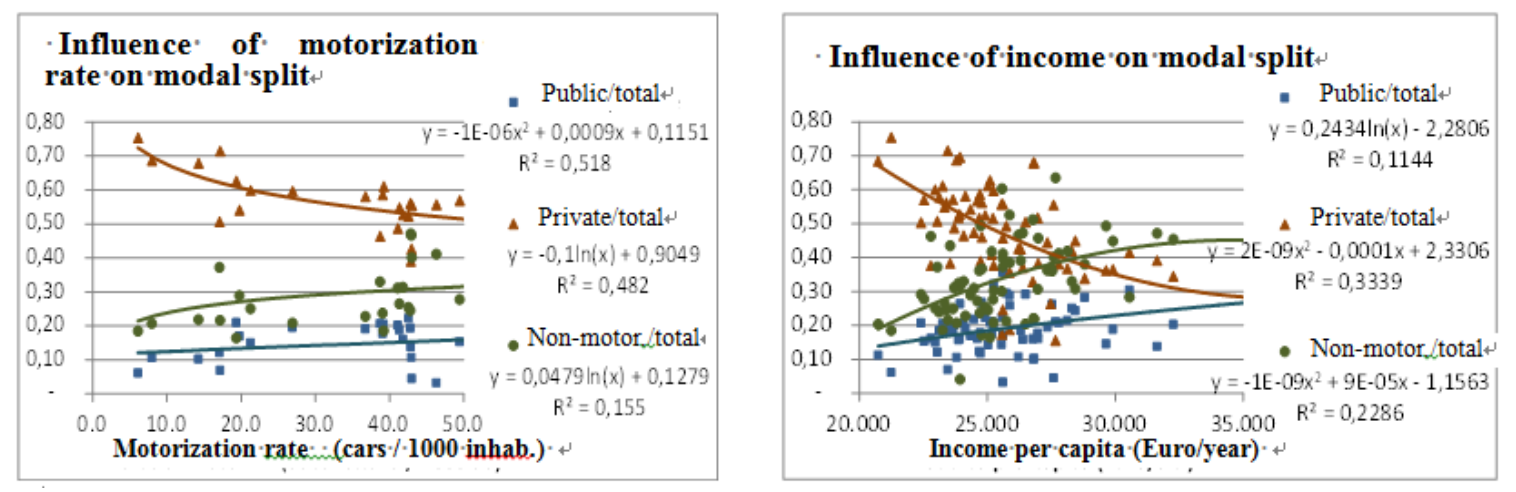

Figure 5. Motorization rate and modal split

Figure 6. Per-capita income and modal split

\subsection{Urban Sprawl and Transport Demand and Supply}

More attention has been paid to the research and interpretation of statistical relationships between certain parameters of mobility and public transport, on the one hand, and the diffusion, fragmentation and urban sprawl indexes, on the other. This is to investigate the effects of the shape of the city on transportation choices of its residents. In this regard it should be noted that some of the chosen settlements indexes have no substantial correlation with the parameters used to describe the mobility. In particular no acceptable correlation was found between the motorization rate, the demand for public transport (average values in the years 2000- 2010), measured in absolute terms (passengers / year) and relative ones (passengers / year / inhabitant), the supply of public transport in the city (million seats.km), the modal split, on the one hand, and the Dynamic Sprawl Index (DSI) on the other hand. This last seems therefore to have no influence on the mobility, as well as the Residual Mean Patch Size (RMPS) and the Low Density Areas (LDA). The cause of this is probably, more than in a lack of significance of the indexes, the difficulties of calculation that was electronically made, basing on maps, by the authors of the source from which the values were taken.

Higher values of $\mathrm{R}^{2}$ (even above 0.3 ) are found in the correlation between mobility and Edge Density (ED) (Figures 7 and 8) and Urban Sprawl (US) indicators (Figures 9 and 10), while still acceptable, although weaker $\left(\mathrm{R}^{2}\right.$ comprised between 0.1 and 0.2$)$, the relationships with the Class Largest Patch Index (LCPI) indicator (figures 11 and 12) 

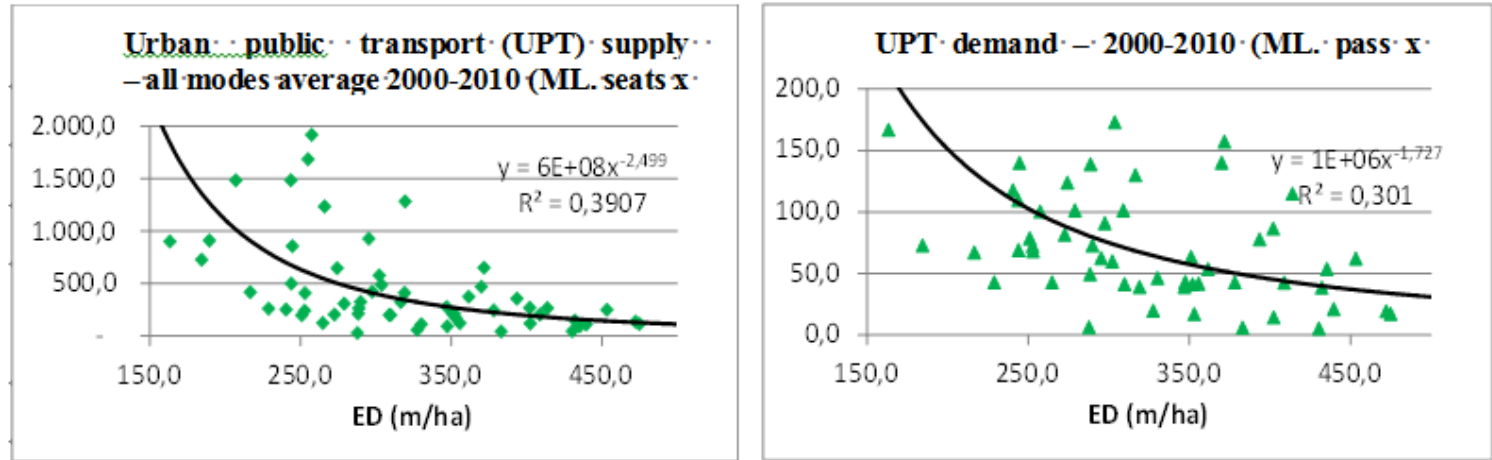

Figura 7. Edge density (ED) and urban public transport supply

Figure 8. Edge density (ED) and urban public transport demand

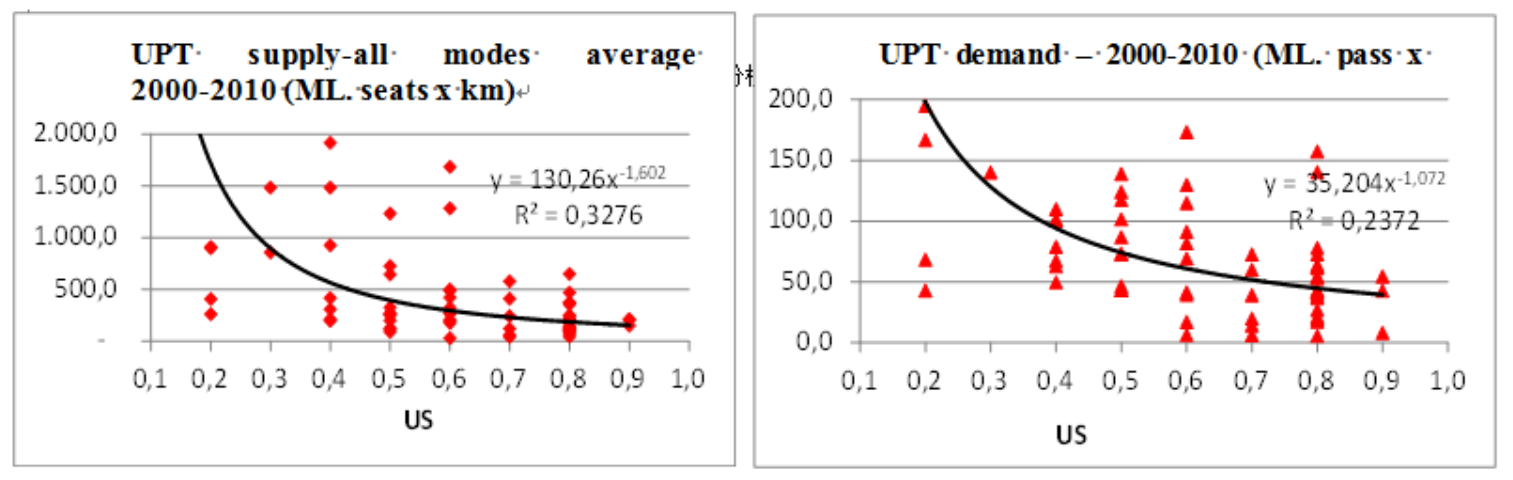

Figure 9. Urban sprawl (US) and urban public transport supply

Figure 10. Urban sprawl (US) and urban public transport demand
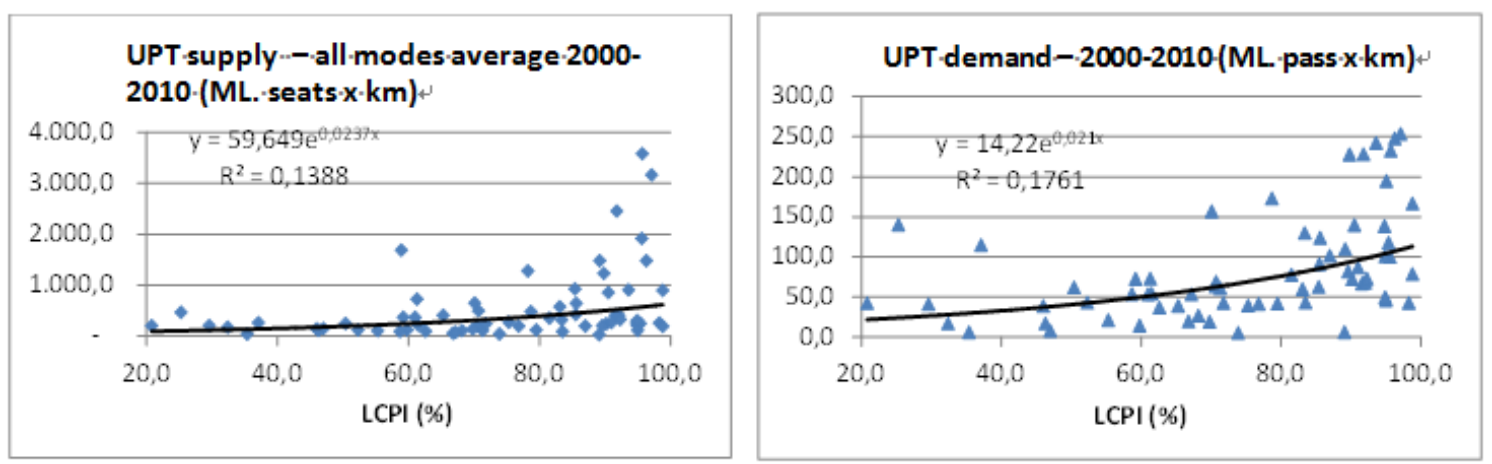

Figure 11. Largest class patch index (LCPI) and urban public transport supply

Figure 12. Largest class patch index (LCPI) and urban public transport demand

From the diagrams we note that ED and US have a negative effect on both the demand and the supply of public transport. The findings can be read as: the increase of weight in terms of number and surface of the areas outside the urban centre and thus the reduction the overall density of the built on the municipality makes it more difficult to subsidize an effective network of public transport, because of the greater mileage required for equal frequencies. This entails reducing the size of the served area and especially the number of rides per day, so 


\section{Macrothink}

that the transport service have less ability to meet the time and location needs of the user and accordingly the latter favours private transport. On the other hand, the higher incidence of the external and / or urban sprawl areas makes it notoriously long and less easy to walk (that is an essential part of the trips by public transport) reducing the rejected distance from the bus stop and then reducing the user. Consequently, the reduction in supply.

The same indicators ED, US and LCPI have been related to the motorization rate obtaining correlation coefficients of the same order of magnitude as those observed in the relations with the demand and supply of transport (Figures 13,14 and 15). Of course the interpolating curves are less than linear and so denote an increase of motorization rate gradually less sensitive to growing of the values of the indicators of dispersion. Despite being expected that to live in areas with poor urbanization and therefore, as discussed above, under-served by public transport can push to buy a car, the diagrams of Figures 13, 14 and 15 seem to prove otherwise. Therefore it's clear that the strong link between income and car ownership, which is discussed above, affects the availability of cars much more than it does the type of urbanization that moreover proved not to be disconnected from income.
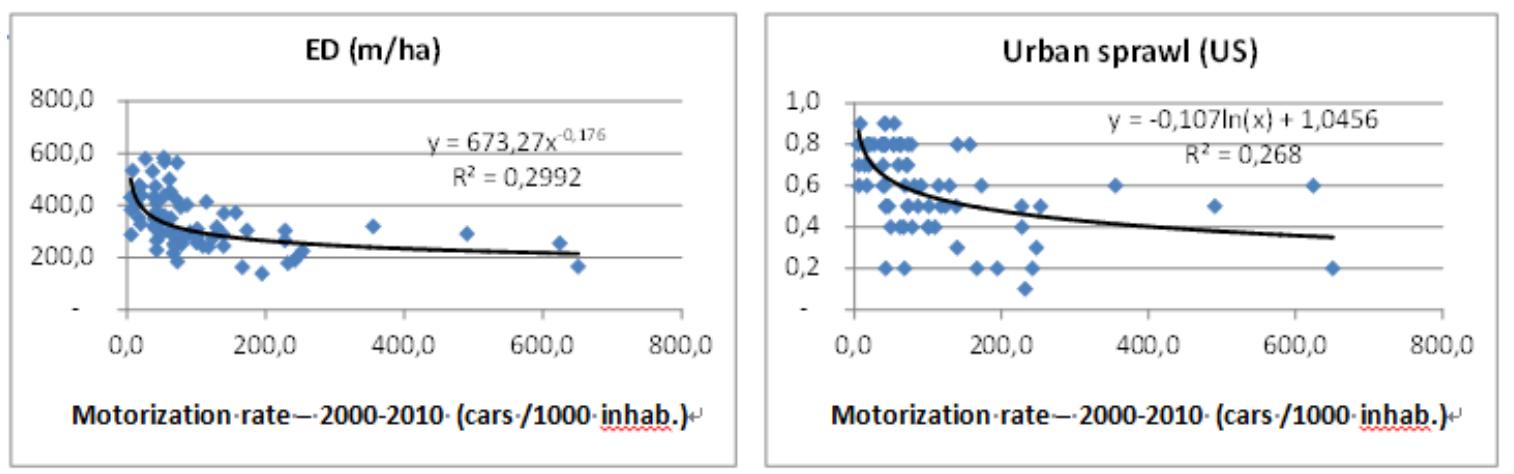

Figure 13. Motorization rate and Edge density (ED)

Figure 14. Motorization rate and Urban sprawl (US)

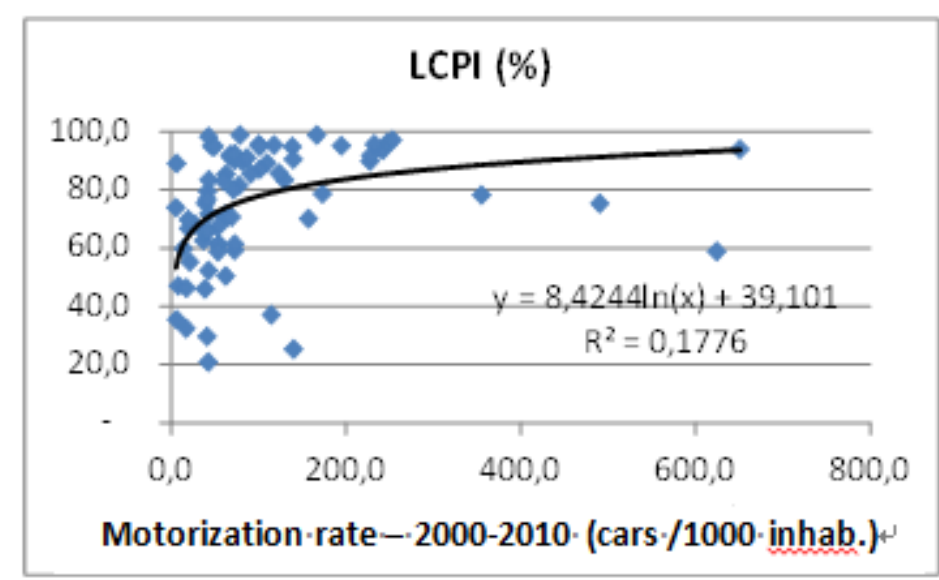

Figure 15. Motorization rate and Largest class patch index (LCPI)

The regression between the different indicators of territorial dispersion and those ones of the modal split confirms the irrelevance on mobility of the parameters LDA (low density area) 


\section{Macrothink}

and DSI (Dynamic Sprawl Index). Instead parameters RMPS (Residual Mean Patch Size), ED (Edge Density) and US (Urban Sprawl) have a relationship with the choice of means in the municipal travels ( $\mathrm{R}^{2}$ is around 0.3) and a more nuanced link with public transport and / or pedestrian traffic $\left(\mathrm{R}^{2}\right.$ lower). These are described in the diagrams of Figures 16 to 19.

The findings shows a more pronounced influence of diffusion fragmentation and urban sprawl phenomena on the use of private transport rather than public transit or pedestrian traffic. The choice of these two last modes is influenced respectively by the effectiveness of the service and the distances and height differences to overcome. In summary we can say that, in urban mobility, the number of additional users of private vehicles following the higher incidence of the urban sprawl phenomena comes from public transport and walkability in proportions depending case to case on the specific characteristics of each the two leaved alternatives.
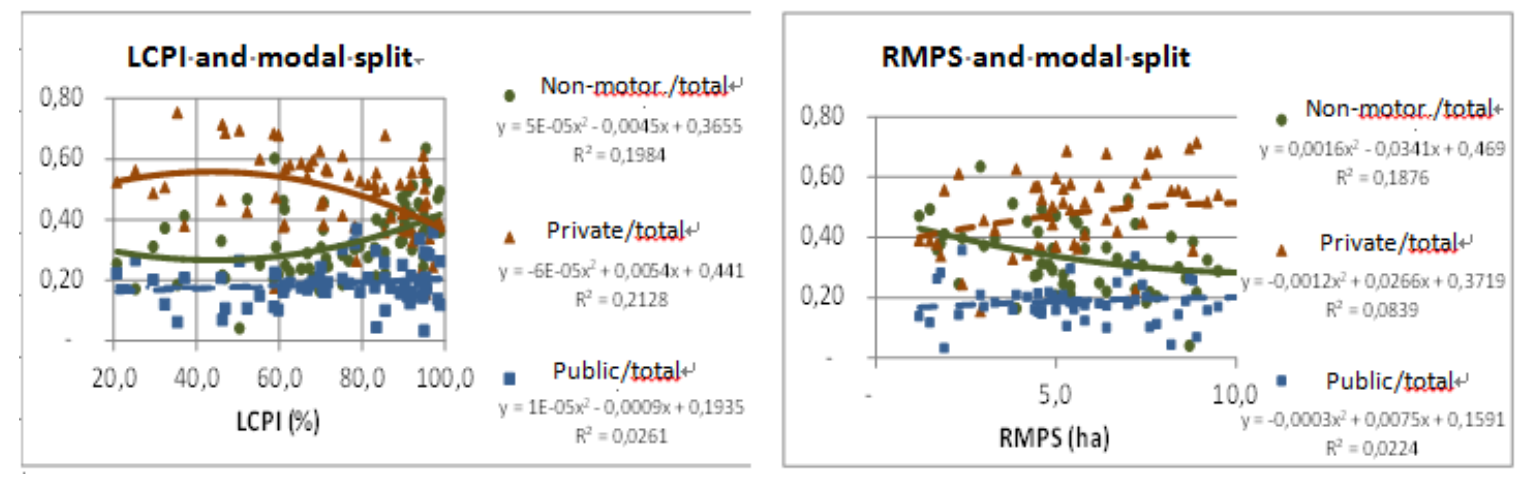

Figure 16. Largest class patch index (LCPI) and modal split

Figure 17. Residual mean patch size (RMPS) and modal split
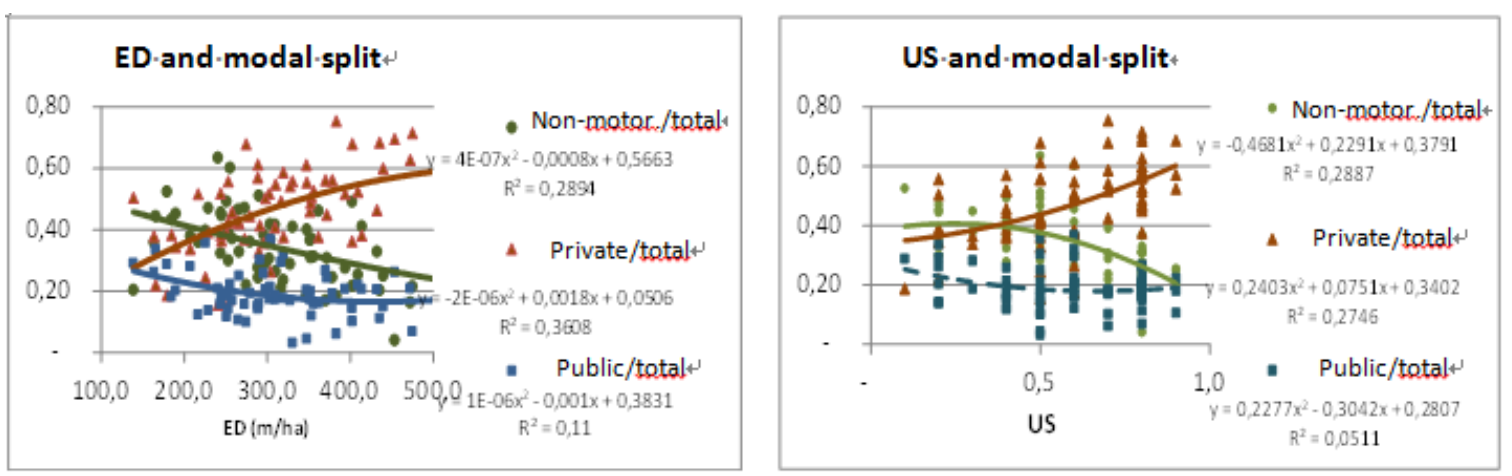

Figure 18. Edge density (ED) and modal split

Figure 19. Urban sprawl (US) and modal split

\subsection{Models for the Modal Choice}

With reference to the sample of the provincial capitals and the urban commuting trips, we searched statistical model formulations having, as dependent variable, the modal split rate (on 


\section{Macrothink}

the total commuting trips) of a transport means and, as independent variables, those settlement and socio-economic features which have proved, by the two-variable regression, to affect more significantly the modal split. We therefore tried several multiple nonlinear regressions between the use percentage of public, private and non-motorized transport, on the one hand, and the variables that showed a better correlation with the modal split, on the other hand, and that is the dispersion parameters ED, US and LCPI, as well as the population, the municipal area, the altitude and the motorization rate. In the choice of the formulations of the models among the many emerged from the regressions, priority was given to those having a higher coefficient of determination and at the same time greater simplicity represented by a smaller number of variables and / or by a linear variation of the latter, even if it means accepting a R2 sometimes slightly lower. Afterwards, we have discarded expressions containing variables US and LCPI as they provided coefficients of determination not greater than those comprising the only indicator ED.

The selected models follow.

Symbols:

Pub. $/$ Tot $=$ rate, on the total, of the trips by public transport (with reference to the only commuter trips to work and study of the citizen inside their own municipal area)

$\operatorname{Priv} . \mathrm{Tot}_{\mathrm{T}}=$ rate, on the total, of the trips by private motorized means (with reference to the same type of trips cited above)

Non.Mot. $/$ Tot $=$ rate, on the total, of non- motorized trips (with reference to the same type of trips cited above)

Sup $=$ surface of the municipal area $\left[\mathrm{km}^{2}\right]$

$A / t=$ altitude, above sea level, of the municipal main centre, $[\mathrm{m}]$

Im = motorization rate [cars/ 1000 inhabitants]

$E D=$ Edge density - dispersion index, defined above as the rate between the perimeter [m] and the surface [ha] of the built area (see the table 3).

$$
\begin{gathered}
\text { Pub. } / \text { Tot }=0.001042 \cdot \operatorname{Im}-1.2 \cdot 10^{-6} \cdot \mathrm{Im}^{2}-0.00014 \cdot E D+3.51 \cdot 10^{-7} \cdot E D^{2} \\
\text { Priv. } / \text { Tot }=-5.5 \cdot 10^{-5} \cdot \operatorname{Im}-0.06901 \cdot \operatorname{Ln}(\operatorname{Im})+0.000745 \cdot E D-5.1 \cdot 10^{-7} \cdot E D^{2} \\
\text { Non.Mot } / \text { Tot }=A+B+C+D
\end{gathered}
$$




\section{Macrothink}

Where: $A=7.46 \cdot 10^{-5} \cdot \operatorname{Sup}+0.894529 \cdot \operatorname{Sup}^{-0.209}$

$$
\begin{aligned}
& B=-0.00086 \cdot A l t-1.0517 \cdot e^{-A l t} \\
& C=-0.00014 \cdot I m+5.54 \cdot 10^{-7} \cdot \mathrm{Im}^{2} \\
& D=-0.00034 \cdot E D+5.61 \cdot 10^{-8} \cdot E D^{2}
\end{aligned}
$$

These models have good reliability, given the large size of the sample from which they were taken. However, it is to consider that, since they not comprise representative variables of all the other phenomena affecting the modal split, among which those ones acting on the generalized cost of the means, they are usable only in situations where these not comprised variables reach the average values found in the sample. Also the use of the models is limited to provincial capital urban centres or other comparable for the territorial covered role.

The regression analysis of the variables included in the proposed models returned the

\begin{tabular}{|c|c|c|c|c|c|c|c|c|c|}
\hline \multicolumn{10}{|c|}{ Statistics of regression } \\
\hline \multirow{5}{*}{$\begin{array}{l}\text { Multiple R } \\
\text { square R } \\
\text { correct } \\
\text { square R } \\
\text { standard error } \\
\text { Observations } \\
\end{array}$} & & 0,738971 & & & & & & & \\
\hline & & 0,546078 & & & & & & & \\
\hline & & 0,517708 & & & & & & & \\
\hline & & 0,048553 & & & & & & & \\
\hline & & 69 & & & & & & & \\
\hline \multirow{2}{*}{\multicolumn{10}{|c|}{ VARIANCE ANALYSIS }} \\
\hline & & & & & & & & & \\
\hline & & dof & SQ & MQ & \multicolumn{2}{|r|}{$\begin{array}{c}\text { Significance } \\
\text { F } \\
\end{array}$} & & & \\
\hline \multirow{4}{*}{$\begin{array}{l}\text { Regression } \\
\text { Residue } \\
\text { Total }\end{array}$} & & 4 & 0,181501 & 0,045375 & 19,24834 & $1,95 \mathrm{E}-10$ & & & \\
\hline & & 64 & 0,150871 & 0,002357 & & & & & \\
\hline & & 68 & 0,332371 & & & & & & \\
\hline & & Factors & $\begin{array}{l}\text { Standard } \\
\text { error }\end{array}$ & Stat $\mathrm{t}$ & $\begin{array}{c}\text { Significance } \\
\text { value }\end{array}$ & $<95 \%$ & $>95 \%$ & $<95 \%$ & $>95 \%$ \\
\hline Intecepts & & 0,112105 & 0,065322 & 1,71618 & 0,090966 & $-0,01839$ & 0,242601 & $-0,01839$ & 0,242601 \\
\hline Variable 1 & Im & 0,001042 & 0,000157 & 6,621942 & $8,53 \mathrm{E}-09$ & 0,000727 & 0,001356 & 0,000727 & 0,001356 \\
\hline Variable 2 & $\operatorname{Im}{ }^{n} \mathbf{2}$ & $-1,2 \mathrm{E}-06$ & $2,48 \mathrm{E}-07$ & $-4,79953$ & 9,92E-06 & $-1,7 \mathrm{E}-06$ & $-7 E-07$ & $-1,7 \mathrm{E}-06$ & $-7 E-07$ \\
\hline Variable 3 & ED & $-0,00014$ & 0,000337 & $-0,42675$ & 0,670997 & $-0,00082$ & 0,00053 & $-0,00082$ & 0,00053 \\
\hline Variable 4 & $E D^{\wedge} \mathbf{2}$ & $3,51 \mathrm{E}-07$ & 4,43E-07 & 0,791807 & 0,431398 & $-5,3 \mathrm{E}-07$ & $1,24 \mathrm{E}-06$ & $-5,3 E-07$ & $1,24 \mathrm{E}-06$ \\
\hline
\end{tabular}
following results.

\section{Model [1]}


Model [2]

\begin{tabular}{|c|c|c|c|c|c|c|c|c|c|}
\hline \multicolumn{10}{|c|}{ Statistics of regression } \\
\hline Multiple R & & 0,738291 & & & & & & & \\
\hline Square R & & 0,545073 & & & & & & & \\
\hline $\begin{array}{l}\text { Correct } \\
\text { square R }\end{array}$ & & 0,51664 & & & & & & & \\
\hline Standard error & & 0,092875 & & & & & & & \\
\hline Observations & & 69 & & & & & & & \\
\hline \multicolumn{10}{|c|}{ VARIANCE ANALYSIS } \\
\hline & & dof & SQ & $\overline{M Q}$ & $\bar{F}$ & $\begin{array}{c}\overline{\text { Significance }} \\
\mathrm{F} \\
\end{array}$ & & & \\
\hline Regression & & 4 & 0,661443 & 0,165361 & 19,170506 & $2,09 \mathrm{E}-10$ & & & \\
\hline Residue & & 64 & 0,55205 & 0,008626 & & & & & \\
\hline \multirow[t]{2}{*}{ Total } & & 68 & 1,213493 & & & & & & \\
\hline & & Factors & $\begin{array}{c}\text { Standard } \\
\text { error }\end{array}$ & Stat t & $\begin{array}{l}\text { Significance } \\
\text { value }\end{array}$ & $<95 \%$ & $>95 \%$ & $<95 \%$ & $>95 \%$ \\
\hline \multirow{5}{*}{$\begin{array}{l}\text { Intecepts } \\
\text { Variable } 1 \\
\text { Variable } 2 \\
\text { Variable } 3 \\
\text { Variable } 4\end{array}$} & & 0,592524 & 0,1623 & 3,650781 & 0,0005279 & 0,268291 & 0,916756 & 0,268291 & 0,916756 \\
\hline & Im & $-5,5 E-05$ & 0,000164 & $-0,33605$ & 0,7379335 & $-0,00038$ & 0,000272 & $-0,00038$ & 0,000272 \\
\hline & $\operatorname{Ln}(\operatorname{Im})$ & $-0,06901$ & 0,023678 & $-2,91437$ & 0,0049055 & $-0,11631$ & $-0,0217$ & $-0,11631$ & $-0,0217$ \\
\hline & ED & 0,000745 & 0,000646 & 1,152433 & 0,2534297 & $-0,00055$ & 0,002036 & $-0,00055$ & 0,002036 \\
\hline & $E D^{\wedge} 2$ & $-5,1 \mathrm{E}-07$ & 8,47E-07 & $-0,59691$ & 0,552671 & $-2,2 E-06$ & $1,19 \mathrm{E}-06$ & $-2,2 \mathrm{E}-06$ & 1,19E-06 \\
\hline
\end{tabular}

Model [3]

\begin{tabular}{|c|c|c|c|c|c|c|c|c|c|}
\hline \multicolumn{10}{|c|}{ Statistics of regression } \\
\hline \multirow{5}{*}{$\begin{array}{l}\text { Multiple R } \\
\text { Square R } \\
\text { Correct } \\
\text { square R } \\
\text { standard error } \\
\text { Observations } \\
\end{array}$} & & 0,693364 & & & & & & & \\
\hline & & 0,480754 & & & & & & & \\
\hline & & 0,411521 & & & & & & & \\
\hline & & 0,086677 & & & & & & & \\
\hline & & 69 & & & & & & & \\
\hline \multicolumn{10}{|c|}{ VARIANCE ANALYSIS } \\
\hline & & dof & SQ & MQ & \multicolumn{2}{|c|}{$\begin{array}{c}\text { Significance } \\
F \\
\end{array}$} & & & \\
\hline \multirow{4}{*}{$\begin{array}{l}\text { Regression } \\
\text { Residue } \\
\text { Total } \\
\end{array}$} & & 8 & 0,417358 & 0,05217 & 6,944021 & $1,95 \mathrm{E}-06$ & & & \\
\hline & & 60 & 0,450774 & 0,007513 & & & & & \\
\hline & & 68 & 0,868132 & & & & & & \\
\hline & & Factors & $\begin{array}{c}\text { Standard } \\
\text { error }\end{array}$ & Stat $\mathrm{t}$ & $\begin{array}{c}\text { Significance } \\
\text { value }\end{array}$ & $<95 \%$ & $>95 \%$ & $<95 \%$ & $>95 \%$ \\
\hline \multirow{2}{*}{$\begin{array}{l}\text { Intecepts } \\
\text { Variable } 1\end{array}$} & & 1,161326 & 0,861284 & 1,348366 & 0,182609 & $-0,5615$ & 2,88415 & $-0,5615$ & 2,88415 \\
\hline & Sup. & $7,46 \mathrm{E}-05$ & $9,68 \mathrm{E}-05$ & 0,771106 & 0,44367 & $-0,00012$ & 0,000268 & $-0,00012$ & 0,000268 \\
\hline \multirow{2}{*}{$\begin{array}{l}\text { Variable } 2 \\
\text { Variable } 3\end{array}$} & Sup.^0,209 & 0,894529 & 0,29338 & 3,049042 & 0,003413 & 0,307681 & 1,481377 & 0,307681 & 1,481377 \\
\hline & Alt & $-0,00086$ & 0,000593 & $-1,45305$ & 0,15142 & $-0,00205$ & 0,000325 & $-0,00205$ & 0,000325 \\
\hline \multirow{3}{*}{$\begin{array}{l}\text { Variable } 4 \\
\text { Variable } 5 \\
\text { Variable } 6\end{array}$} & $\mathrm{e}^{\wedge}$-Alt. & $-1,0517$ & 0,863081 & $-1,21854$ & 0,22779 & $-2,77811$ & 0,674723 & $-2,77811$ & 0,674723 \\
\hline & Im & $-0,00014$ & 0,000284 & $-0,47662$ & 0,635361 & $-0,0007$ & 0,000433 & $-0,0007$ & 0,000433 \\
\hline & $\operatorname{Im} \wedge 2$ & $5,54 \mathrm{E}-07$ & 4,47E-07 & 1,238897 & 0,220208 & $-3,4 E-07$ & $1,45 E-06$ & $-3,4 \mathrm{E}-07$ & $1,45 \mathrm{E}-06$ \\
\hline Variable 7 & ED & $-0,00034$ & 0,000639 & $-0,52593$ & 0,600878 & $-0,00161$ & 0,000942 & $-0,00161$ & 0,000942 \\
\hline Variable 8 & $E^{\wedge} 2$ & 5,61E-08 & $8,3 \mathrm{E}-07$ & 0,06764 & 0,946297 & $-1,6 \mathrm{E}-06$ & $1,72 \mathrm{E}-06$ & $-1,6 \mathrm{E}-06$ & $1,72 \mathrm{E}-06$ \\
\hline
\end{tabular}

\section{Discussion}

Finally we wondered what might be the consequences, on the modal split of mobility, of a different amount of diffusion, fragmentation and urban sprawl phenomena in the considered capitals, represented by the indexes that showed a stronger correlation with the mobility and that is ED (Edge Density) and US (Urban Sprawl). So we have built two scenarios, one contemplating the reduction of $50 \%$ for the ED and the other the same percentage reduction 


\section{Macrothink}

of US. The first, since the meaning of the index ED (ratio between the perimeter and area of the built), implies a greater overall density of the city that in principle has, as a result, shorter trips. The second involves a building in which the identified areas of low density have a lower incidence, compared to the detected current situation, on the set of all the built-up areas throughout the municipality, with consequences on mobility similar to the other scenario. The purpose is to estimate the expected change in each scenario, compared to the current situation, in the number of trips by private vehicles and public transport, and the consequences in terms of reductions in $\mathrm{CO}_{2}$ emissions and higher fare revenues for the public transport service.

To appraise the modal split in the two scenarios we used the best interpolating functions emerging from the simple regressions, between each of the two territorial variables, ED and US, and the share of trips both by private and public means. However, in the scenario that entails the reduction of $50 \%$ of ED we preferred to use logarithmic functions (rather than polynomial) that, although gets an $\mathrm{R}^{2}$ lowest compared to the polynomial one, respond better within the interval of variation of the detected values for the same index.

Therefore, the relations used to verify the scenarios are:

$$
\begin{gathered}
\text { Pub. } / \text { Tot }=-0.062 \cdot \operatorname{Ln}(E D)+0.5481 \\
\text { Priv. } / \text { Tot }=0.2442 \cdot \operatorname{Ln}(E D)-0.9296 \\
\text { Pub. } \text { Tot }_{\text {Tot }}=0.2277 \cdot \mathrm{US}^{2}-0.3042 \cdot \mathrm{US}+0.2807 \\
\text { Priv. } / \text { Tot }_{\text {Tot }}=0.2403 \cdot \mathrm{US}^{2}+0.0751 \cdot \mathrm{US}+0.3402
\end{gathered}
$$

In detail, we provided the variation of the modal choice as the difference between the share estimated by the interpolating function for the assumed scenario, characterized by reduced values of ED and US at 50\%, and the share estimated using the same function with reference to the current scenario characterized by the observed values of ED and US. The change obtained in modal split was multiplied by the number of daily commuters trips to work reported by ISTAT (Italian Institute of Statistics) in the last Census (ISTAT, 2011), to get the number of daily trips of the same type in decline or in addition, respectively for the private and the public transport. The data used for external variables involved are summarized in Table 6. 


\section{MInstitute Macrothink $^{\text {Int }}$}

Table 6. Values assumed for the involved parameters in the mobility assessment related to the two territory scenarios (based on data of Italian Ministry of Infrastructures and Transports, 2014 and of Legambiente, 2013)

\begin{tabular}{|c|c|c|c|c|c|}
\hline $\begin{array}{c}\text { Load factor of } \\
\text { cars }\end{array}$ & $\begin{array}{c}\text { Average length of } \\
\text { urban trips }\end{array}$ & $\begin{array}{c}\text { Marginal cost of } \\
\text { cars }\end{array}$ & $\begin{array}{c}\text { Average fare of } \\
\text { public transport }\end{array}$ & $\begin{array}{c}\mathrm{CO}_{2} \text { emission/ } \\
\text { /car x km }\end{array}$ & $\begin{array}{c}\mathrm{CO}_{2} \text { value on the } \\
\text { carbon market }\end{array}$ \\
\hline pass./car & $k m$ & $\epsilon / k m$ & $\epsilon$ & $g / k m$ & $\epsilon / t$ \\
\hline 1.3 & 3 & 0.15 & 0.8 & 200 & 7 \\
\hline
\end{tabular}

The results, summarized in Tables 7 and 8, report values that, although overall important for the set of the examined cities, however do not appear significant when compared to the population involved. This allows we to say that the effects of urban sprawl on mobility does not seem heavy in economic terms, although presenting important consequences on the quality of life for residents and the city environment. In fact the variation assumed for ED (the indicator that produces greater effects on modal split) results in a decrease of the users of private transport and increasing of those of public transport in urban journeys that on average were respectively $-17 \%$ and $+4 \%$. This results in an annual savings of 50.5 million $€ /$ year on the marginal cost of transportation and 67,000 $\mathrm{t} /$ year on emissions $\mathrm{CO}_{2}$ as well as an increase of fare revenues for the public transport of 21.5 million $€ /$ year . These values refer to the set of about 70 examined provincial capitals (on a total number of 110) and would grow considerably if the estimate was extended to all Italian capitals and other non-capital municipalities of a certain size. In addition a complete estimate should take account of the unsystematic and for reasons other than work trips that may affect the total mobility to more than $50 \%$ and for which unfortunately, as already mentioned, there are no consistent data extended at least to the provincial capitals. Finally, it is to note that the lack of homogeneous data on the length of the trips did not allow us to analyse the effects of the urban dispersion phenomena on this important aspect of mobility which obviously impacts on the fuel consumption and thus on emissions but also on the possibility to move on foot or by bike. On the other hand, favourable consequences related to the increase in this last type of mobility (which registered a significant raise in the built scenarios) on the liveability of the urban environment and on people's health are not negligible.

2 The average length of the trips, for each city, was deduced by the formulas:

$$
L_{i}=\frac{L m \cdot\left(P_{i}\right)^{1 / 4} \cdot\left(S_{i}\right)^{1 / 4}}{(P m)^{1 / 4} \cdot(S m)^{1 / 4}}
$$

Where $\mathrm{Li}, \mathrm{Pi}$, and $\mathrm{Si}$ are respectively the average length of the trip, the population (number of inhabitants) and the surface for the municipal area of the i th city, while Lm, Pm ed Sm are the average values of the same variables computed for the considered capital. 
Table 7. Overall impact of the scenario involving the reduction of ED (Edge Density) at 50\%

\begin{tabular}{|c|c|c|c|c|c|c|c|c|c|c|}
\hline & & & $\begin{array}{l}\text { lal split c } \\
\text { differenc }\end{array}$ & $\begin{array}{l}\text { hange } \\
\text { ce) }\end{array}$ & & mpact on $\mathrm{p}$ & rivate trans & & $\begin{array}{r}\text { Impact } \\
\text { tra }\end{array}$ & $\begin{array}{l}\text { on public } \\
\text { nsit }\end{array}$ \\
\hline & difference & $\begin{array}{c}\text { pubblic } \\
\text { / total }\end{array}$ & $\begin{array}{l}\text { private } \\
\text { / total }\end{array}$ & $\begin{array}{c}\text { non-mot./ } \\
\text { total }\end{array}$ & $\begin{array}{l}\text { Saved } \\
\text { mileage }\end{array}$ & $\begin{array}{c}\text { Saved } \\
\text { marginal } \\
\text { cost }\end{array}$ & $\begin{array}{c}\text { Saved } \mathrm{CO}_{2} \\
\text { emissions }\end{array}$ & $\begin{array}{c}\text { Value of } \\
\mathrm{CO}_{2} \\
\text { emissions }\end{array}$ & $\begin{array}{c}\text { Acquired } \\
\text { users }\end{array}$ & $\begin{array}{c}\text { Additional } \\
\text { revenue }\end{array}$ \\
\hline & $(\mathrm{m} / \mathrm{ha})$ & & & & $\begin{array}{c}\text { ML } \\
\text { car.x.km } \\
\text { /year }\end{array}$ & $\begin{array}{c}\text { ML Euro / } \\
\text { year }\end{array}$ & $\begin{array}{l}\mathrm{tx} \text { 1000/ } \\
\text { year }\end{array}$ & $\begin{array}{c}\text { Euro x } 1000 \\
\text { / year }\end{array}$ & $\begin{array}{c}\text { ML N }^{\circ} / \\
\text { year }\end{array}$ & $\begin{array}{c}\text { ML Euro / } \\
\text { year }\end{array}$ \\
\hline Overall & & & & & 336.6 & 50.5 & 67.3 & 471 & 26.9 & 21.5 \\
\hline Average & -166.26 & $+4 \%$ & $-17 \%$ & $+13 \%$ & 4.9 & 0.7 & 1.0 & 6.8 & 0.4 & 0.3 \\
\hline $\begin{array}{c}\text { Std. } \\
\text { Deviation }\end{array}$ & 53.19 & 0.00 & 0.00 & 0.00 & 15.8 & 2.4 & 3.2 & 22.1 & 0.7 & 0.5 \\
\hline Minimum & -291.70 & $+4 \%$ & $-17 \%$ & $13 \%$ & 0.3 & 0.04 & 0.06 & 0.4 & 0.07 & 0.06 \\
\hline Maximum & -69.30 & $+4 \%$ & $-17 \%$ & $13 \%$ & 126.8 & 19.0 & 25.3 & 177.5 & 4.7 & 3.8 \\
\hline
\end{tabular}

Table 8. Overall impact of the scenario involving the reduction of US (Urban Sprawl) at 50

\begin{tabular}{|c|c|c|c|c|c|c|c|c|c|c|}
\hline \multirow{3}{*}{ 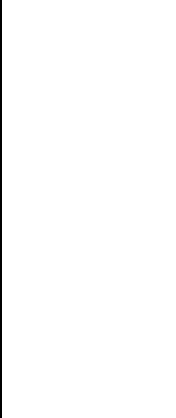 } & \multirow{2}{*}{$\begin{array}{c}\text { US } \\
\text { difference }\end{array}$} & \multicolumn{3}{|c|}{ Modal split change (difference) } & \multicolumn{4}{|c|}{ Impact on private transport } & \multicolumn{2}{|c|}{ Impact on public transit } \\
\hline & & $\begin{array}{c}\text { pubblic / } \\
\text { total }\end{array}$ & $\begin{array}{c}\text { private / } \\
\text { total }\end{array}$ & $\begin{array}{c}\text { non-mot./ } \\
\text { total }\end{array}$ & $\begin{array}{l}\text { Saved } \\
\text { mileage }\end{array}$ & $\begin{array}{c}\text { Saved } \\
\text { marginal } \\
\text { cost }\end{array}$ & $\begin{array}{c}\text { Saved } \mathrm{CO}_{2} \\
\text { emissions }\end{array}$ & $\begin{array}{c}\text { Value of } \mathrm{CO}_{2} \\
\text { emissions }\end{array}$ & $\begin{array}{c}\text { Acquired } \\
\text { users }\end{array}$ & $\begin{array}{c}\text { Additional } \\
\text { revenue }\end{array}$ \\
\hline & (ha/ha) & & & & $\begin{array}{c}\text { ML } \\
\text { car.x.km } \\
\text { /year }\end{array}$ & $\begin{array}{l}\text { ML Euro / } \\
\text { year }\end{array}$ & t x 1000/year & $\begin{array}{c}\text { Euro x } 1000 / \\
\text { year }\end{array}$ & $\begin{array}{c}\mathrm{MLN}^{\circ} / \\
\text { year }\end{array}$ & ML Euro / year \\
\hline Overall & & & & & 118.2 & 17.7 & 23.6 & 160.0 & 16.3 & 13.1 \\
\hline Average & -0.29 & $+2 \%$ & $-9 \%$ & $7 \%$ & 1.7 & 0.3 & 0.3 & 2.4 & 0.2 & 0.2 \\
\hline $\begin{array}{c}\text { Std. } \\
\text { Deviation }\end{array}$ & 0.10 & 0.01 & 0.05 & 0.06 & 5.7 & 0.9 & 1.1 & 8.0 & 0.5 & 0.4 \\
\hline Minimum & -0.45 & $0 \%$ & $-18 \%$ & $-1 \%$ & 0.08 & 0.01 & 0.02 & 0.1 & -0.007 & -0.005 \\
\hline Maximum & -0.05 & $3 \%$ & $-1 \%$ & $18 \%$ & 47.8 & 7.2 & 9.6 & 66.9 & 3.6 & 2.9 \\
\hline
\end{tabular}

\section{Conclusion}

This research helps to expand the knowledge about the effects of urban sprawl on some features of mobility and to highlight some of the difficulties encountered in this type of analysis.

First it is to note that the emerged failure correlation between some indexes of the urban 
dispersion and the parameters set to describe aspects of mobility. This raises a question: these indexes are not sufficiently representative or their values do not reflect the investigated scenarios? Assuming that, as confirmed also by other researches, the territory settlement characteristics influence the mobility and in particular the modal split and given that these indicators are, by their nature, representative at least of one feature of the analysed settlement, it is more likely that the approximate calculation techniques, the chart type, used by the bibliographic source from which those values are derived, have resulted in incorrect estimates. Then this problem is limited to the present work. But generally, however, we have to highlight the difficulties inherent in the choice of territorial indexes. In fact, although the literature offers different indexes and new ones can be built, unfortunately no one is universality acknowledged, by itself or in combination with other specifically set, to represent univocally the characteristics of the settlement to study. Therefore it is advisable that the sector's research has, as its primary objective, the development and validation of an indicator system able to measure uniquely and exhaustively the settlement characteristics of the city, at least the ones affecting mobility. The goal, though ambitious because of the difficulty to describe, through quantitative parameters, predominantly qualitative settlement characteristics, however, is the prerequisite to create models reproducing the relationship between the built environment and transport. These models are essential to support the settlement choices without neglecting their major impacts on mobility and the consequences of the latter on energy consumption and emissions, as well as the standard requirement of public transport.

Based on the findings of the literature and of this study, we confirmed that effects of urban sprawl on mobility consist essentially in extension of trips and reducing of the effectiveness of public transport which, by its nature, is not suitable to serve, with acceptable costs, a widespread demand. This leads to a greater use of private vehicles at the expense of public transport and non-motorized mobility. Therefore one of the strategic objectives of the planning legislation should be to discourage urban sprawl by limiting the use of land and promoting the recovery, restoration and reuse of existing buildings that, among other things, generally presents considerable settlement density. This, even if it goes in the direction of a reduction of the internal and external costs of mobility, does not imply in itself an appropriate response to the mobility needs. In fact we must not neglect that the old or at least not recently built city has no suitable space to ensure massive use of private cars without consequent high environmental and congestion costs. On the other hand, the availability of private vehicles has accustomed us to high levels of comfort and of ability to shift, not even conceivable by public transport, especially if traditional. So the built restoration shall be accompanied by the construction of infrastructures for non-conventional and / or on its own runway public transport services, able to offer services with characteristics closer to private transport but which do not have the drawbacks of the latter. In short, the choice between the new development and restoring of the existing settlements should always quantify and take into account the cost of mobility resulting from the urban sprawl generated by the first alternative and the cost of an expansion of accessibility based on public transport, in particular on non-conventional transport systems, necessary in the second alternative. 


\section{References}

Alpkokin P., Cheung C., Black J., \& Hayashi Y. (2008). Dynamics of clustered employment growth and its impacts on commuting patterns in rapidly developing cities. Transportation Research Part A, 42, 427-444. http://dx.doi.org/10.1016/j.tra.2007.11.002

Axisa J. J., Scott D. M., \& Newbold K. (2012). Factors influencing commute distance: a case of study of Toronto's commuter shed. Journal of Transport Geography, 24, 123-129. http://dx.doi.org/10.1016/j.jtrangeo.2011.10.005

Bonomo R., Di Stefano R., Perini P., Ricci V., \& Vita L. (2014). Qualità dell'Ambiente urbano - X rapporto ISPRA - cap. 2 Suolo e Territorio_par. 2.14_La cartografia geologica delle grandi aree urbane italiane: Benevento, L'Aquila e Viterbo, Technical Report December 2014.

Cervero, R., \& Landis, J. (1991). Suburbanization of jobs and journey to work. Scholarship, University of California. http://escholarship.org/uc/item/29p3n2wf

Cervero, R., Sarmiento, O. L., Jacoby, E., Gomez, L. F., \& Neiman, A. (2009). Influences of Built Environments on Walking and Cycling: Lessons from Bogota', International Journal of Sustainable Transportation, 3, 203-226. http://dx.doi.org/10.1080/15568310802178314

Crane, R., \& Chatman, D. (2002). Traffic and sprawl: evidence from U.S. commuting, 1985 to 1997. Proceedings of the Colloquium on "Sprawl in Western Europe and United States", Chateau del la Bretesche, Massillac, France, July 2002.

Duncan M. J., Winkler, E., Sugiyama, T., Cerin, E., duToit, L., Leslie, E., \& Owen N. (2010). Relationships of land use mix with walking for transport: do land uses and geographical scale matter?. Journal Urban Health, 87(5), 782-95. http://dx.doi.org/10.1007/s11524-010-9488-7

Fondazione Filippo Caracciolo, (2013). Muoversi meglio in città per muovere l'Italia Analisi e proposte per un progetto di mobilità urbana. http://www.aci.it/fileadmin/documenti/notizie/Eventi/Studio_ACI_Fondazione_Caracciolo_s u_mobilita_urbana.pdf

Frank, L. D., Sallis, J. F., Conway, T. L., Chapman, J. E., Saelens B. E., \& Bachman, W. (2006). Many Pathways from Land Use to Health: Associations between Neighborhood Walkability and Active Transportation, Body Mass Index, and Air Quality. Journal of the American Planning Association, 72(1), 75-87. http://dx.doi.org/10.1080/01944360608976725

Gordon, P., Richardson, H. W., \& Jun, M. J. (1991). The commuting paradox evidence from the top twenty, Journal of the American Planning Association, 57(4), 416-420. http://dx.doi.org/10.1080/01944369108975516

ISTAT (Italian National Institute of Statistics). (2011). 15 ${ }^{\text {th }}$ Population Census, 2011. http://www.istat.it/storage/cartografia/matrici_pendolarismo/matrici_pendolarismo_2011.zip

Leck, E. (2006). The Impact of Urban Form on Travel Behavior: A Meta-Analysis. Berkeley Planning Journal, 19(1), 37-58. 


\section{Macrothink Institute $^{\mathrm{TM}}$}

Legambiente,

(2013).

Environmental Management and Sustainable Development

ISSN 2164-7682 2016, Vol. 5, No. 1

Ministero delle infrastrutture e dei trasporti (MIT), 2014. Dipartimento per le Infrastrutture, i Sistemi Informativi e Statistici. Conto Nazionale Trasporti 2013-2014, Roma - Istituto Poligrafico e Zecca dello Stato S.p.A. http://www.mit.gov.it/mit/mop_all.php?p_id=24349

Olaru, D., Curtis, C. (2015). Designing TOD precincts: accessibility and travel patterns., 6-26

Parady, G. T., Chikaraishi, M., Takami, K., Ohmori, N., \& Harata, N. (2015). On the effect of the built environment and preferences on non-work travel: Evidence from Japan. European Journal of Transport and Infrastructure Research, 15(1), 51-65.

Sohn, J. (2005). Are commuting patterns a good indicators of urban spatial structure?. Journal of Transport Geography. 306-317. http://dx.doi.org/10.1016/j.jtrangeo.2004.07.005

Travisi, C. M., Camagni, R., \& Nijkamp, P. (2010). Impacts of urban sprawl and commuting: a modelling study for Italy. Journal of Transport Geography, 18, 382-392. http://dx.doi.org/10.1016/j.jtrangeo.2009.08.008

Vandersmissen, M. H., Villeneuve P., \& Thériault, M. (2003). Analyzing changes in urban form and commuting time. The Professional Geographer, 55(4), 446-463. http://dx.doi.org/10.1111/0033-0124.5504004

Zolnik, E. J. (2011). The effect of sprawl on private-vehicle commuting outcomes. Environment and Planning A, 43, 1875-1893. http://dx.doi.org/10.1068/a42466

\section{Copyright Disclaimer}

Copyright for this article is retained by the author(s), with first publication rights granted to the journal.

This is an open-access article distributed under the terms and conditions of the Creative Commons Attribution license (http://creativecommons.org/licenses/by/3.0/). 